\title{
Effect of intercropping narrow-leafed lupin with spring triticale on the abundance and diversity of rove beetles
}

\author{
Iwona Gruss ${ }^{(1)}$, Jacek Piotr Twardowski ${ }^{(1)}$, Michał Hurej ${ }^{(1)}$, Marcin Kozak ${ }^{(2)}$ \\ (1) Wroclaw University of Environmental and Life Sciences. Department of Plant Protection. Grunwaldzki 24a. \\ PL-50-363 Wroclaw (Poland). E-mail: iwona.gruss@upwr.edu.pl \\ (2) Wroclaw University of Environmental and Life Sciences. Institute of Agroecology and Plant Production. Grunwaldzki \\ 24a. PL-50-363 Wroclaw (Poland).
}

Received 31 March 2018, accepted 24 October 2018, available online 27 November 2018.

This article is distributed under the terms and conditions of the CC-BY License (http://creativecommons.org/licenses/by/4.0)

Description of the subject. Intercropping is a kind of polyculture, growing two or more crops together. This practice should improve pest management mainly by increasing predator diversity. It was hypothesized that the intercropping of narrowleafed lupin with spring triticale would increase the number and diversity of rove beetles compared to monocultures of the aforementioned crops.

Objectives. The aim of the research was to determine the effect of intercropping of narrow-leafed lupin with spring triticale on rove beetle abundance and diversity.

Method. Over a three-year period, rove beetles were trapped with the use of pitfall traps, and adults were identified to species. The experiment was carried out on a narrow-leafed lupin and spring triticale crop sown as monocultures, and on two mixtures with different proportions of lupin seeds.

Results. In total, in all treatments 100 rove beetle species were found, classified into three trophic groups. The most numerous forms were predatory zoophages, which were followed by parasites and saprophages. Staphylinidae abundance and ecological significance decreased with increasing degree of habitat diversity in comparison to crops grown in the pure stand. The same response to intercropping was observed in the case of zoophages.

Conclusions. Contrary to what was hypothesized, the abundance and diversity of rove beetle decreased when narrow-leafed lupin and spring triticale were grown together compared to their monoculture. Presumably, the higher abundance of rove beetle in lupin and spring triticale grown in the pure stand is mostly the result of better food supply in monocultures during the whole season.

Keywords. Lupinus augustifolius, x Triticosecale Wittm., Staphylinidae, intercropping, trophic levels.

Effet de la culture intercalaire de lupin à feuilles étroites et de triticale de printemps sur l'abondance et la diversité des staphylins

Description du sujet. La culture intercalaire est un type de polyculture dans laquelle deux cultures, ou plus, sont associées. Cette pratique devrait améliorer la lutte antiparasitaire principalement en augmentant la diversité des prédateurs. L'hypothèse suivante a été émise : la culture intercalaire de lupin à feuilles étroites et de triticale printanier augmente le nombre et la diversité des staphylins présents, comparativement à des cultures en semis purs.

Objectifs. Le but de la recherche était de déterminer l'effet de la culture intercalaire de lupin à feuilles étroites avec le triticale de printemps sur l'abondance et la diversité des staphylins.

Méthode. Sur une période de trois ans, les staphylins ont été piégés avec l'utilisation de pièges à fosse et les adultes identifiés jusqu'au stade de l'espèce. Les traitements expérimentaux ont consisté en une culture de lupins à feuilles étroites et de triticale de printemps en peuplement pur et de ses deux mélanges avec une proportion différente de graines de lupin.

Résultats. Cent espèces de staphylins ont été trouvées, classées en trois groupes trophiques. Les plus nombreux étaient zoophages, suivis par les parasitoïdes et les saprophages. L'abondance et l'importance écologique des Staphylinidae diminuaient avec l'augmentation de la diversité de l'habitat, par rapport aux cultures pratiquées en peuplement pur. La même réponse à la culture intercalaire a été observée dans le cas des zoophages.

Conclusions. Contrairement à l'hypothèse de départ, notre recherche démontre que l'abondance et la diversité des staphylins sont moindres dans les cultures intercalaires que dans les monocultures de lupin à feuilles étroites et de triticale de printemps. 
L'abondance plus élevée de staphylins dans les cultures en semis purs de lupin et de triticale de printemps peut être expliquée par une meilleure alimentation en monoculture durant toute la saison.

Mots-clés. Lupinus augustifolius, x Triticosecale Wittm., Staphylinidae, interculture, niveaux trophiques.

\section{INTRODUCTION}

Staphylinidae are among the most numerous and most important families of epigeic invertebrates within agroecosystems, with respect to their activity and abundance (Obrtel, 1971). More than 47,000 species are described worldwide, and from 1,500 to 1,700 species are known in Central Europe (Zerche, 1994; VásquezVélez et al., 2010). They are effective predators in arable fields, and thus are useful in biological pest control (Krooss \& Schaefer, 1998; Balog et al., 2008). Their average body size is in the range between 0.5 to $35 \mathrm{~mm}$, which is related to their role in the ecosystem. Smaller species have contact with soil crevices, while larger ones occur more on the soil surface (Bohac, 1999). Most of the staphylinids are unspecialized predators of different pests threatening field crops, e.g. aphids or caterpillars. Their preying on aphids has especially been taken into consideration (Good \& Giller, 1991; Birken \& Cloyd, 2007). Apart from predators, there are species classified as mycophagous, saprophagous and parasitoids (Smith et al., 2008). A distinct response was observed in relation to the relief of the agricultural landscape, soil properties and crop change (Bohac, 1999). In Hungary rove beetle species composition differs by crop (apple, pear and wheat), as well as soil composition and surrounding habitat (Balog et al., 2008).

Intercropping is a form of polyculture, growing two or more crops together. This practice is used more commonly in tropical zones (Altieri, 1991). Interactions between different plants can be both inhibiting and stimulatory on plant growth and yield (Lithourgidis et al., 2011; Tooker \& Frank, 2012). Therefore, in the design of intercropping it is important to minimize competition and maximize the complementation among plant species (Altieri \& Letourneau, 1982). Generally, the benefits are reduced weed competition, increased pest and pathogen control, as well as better plant growth (Vandermeer, 1989; Theunissen, 1994). Root (1973) predicted that greater numbers of beneficial organisms will occur in polycultures than in monocultures. Some reasons for this are the greater distribution of nectar and pollen sources, greater ground cover, and more herbivorous species, which constitute prey for predators (Altieri, 1991; Andow, 1999; Birkhofer et al., 2014). Petremand et al. (2016) found in vineyards that ground covered with spontaneous differentiated vegetation seemed to favor ground beetles throughout the sampling period. Increasing crop diversity should improve pest management. This would be possible mainly due to increasing predator abundance (Altieri, 1991). The enemies' hypothesis holds that predatory insects are more effective at controlling herbivores in diverse systems of vegetation than in simple ones (Root, 1973). Does this only mean that the predators kill herbivores at higher rates in polycultures than in monocultures, or also that those enemies occur in greater abundance in more diverse habitats? In the present study it was hypothesized that the intercropping of narrow-leafed lupin with spring triticale would increase the number and diversity of rove beetles in arable fields. Clough et al. (2007) found positive response of saprophagous and predatory staphylinids to organic agriculture. Purtauf et al. (2002) observed differences in the abundance of ground beetle feeding groups according to landscape simplification, and Kosewska et al. (2016) to organic and conventional farming in legume crops. According to these works, an assumption has been made that the response of rove beetles to intercropping might be different depending on the trophic group. Especially, the abundance of zoophages should be greater in intercropping treatments in comparison to crops grown in the pure stand.

\section{MATERIALS AND METHODS}

\subsection{Description of the study site}

The field experiment was carried out in 2010-2012, at the Experimental Research Station at Pawłowice of Wrocław University of Environmental and Life Sciences, located in Lower Silesia, Poland (51.166903 $\mathrm{N}, 17.097462 \mathrm{E}$ ). The effect of four different treatments on rove beetle communities was studied (Table 1). Treatment 1 (T1) was a pure stand with $100 \%$ of sown seeds of narrow-leafed lupin (cv. 'Graf'). Similarly, treatment 6 (T6) was established with just spring triticale (cv. 'Dublet'). The two other treatments (T3 and T4) were mixtures of lupin and triticale, with different proportions of sown seeds. The number of seeds sown in the pure stand, lupin and spring triticale, was recommended by the breeder (Smolice sp. z o.o, Poland). The intercropping design (the proportions and number of seeds in the mixtures) was chosen after the analysis of the total protein yield from 1 ha and requirements for each plant. The experiment was conducted in four replicates in a randomized complete block design. The size of each plot was $15 \mathrm{~m}^{2}(10 \mathrm{~m} \times$ $1.5 \mathrm{~m}$ ) and they were separated by a buffer zone of $0.3 \mathrm{~m}$ wide bare soil. For all plots, mineral fertilization 
Table 1. Characteristics of experimental treatments with the number of seeds sown per $\mathrm{m}^{2}$ of narrow-leafed lupin and spring triticale - Caractéristiques des traitements expérimentaux avec le nombre de graines de lupin à feuille étroite et de triticale de printemps semées par $m^{2}$ dans les différents traitements de l'expérience.

\begin{tabular}{lccc}
\hline \multirow{2}{*}{ Treatment number } & \multicolumn{2}{c}{ Number of seeds per $\mathbf{~ m}^{\mathbf{2}}$} & \multirow{2}{*}{$\%$ of narrow-leafed lupin seeds in the mixture } \\
\cline { 2 - 3 } & Narrow-leafed lupin & Spring triticale & \\
\hline 1 & 100 & 0 & 100 \\
3 & 60 & 160 & 27 \\
4 & 40 & 240 & 14 \\
6 & 0 & 400 & 0 \\
\hline
\end{tabular}

was applied each year, at the end of March: $\mathrm{P}_{2} \mathrm{O}_{5}$ $60 \mathrm{~kg}, \mathrm{~K}_{2} \mathrm{O}-120 \mathrm{~kg}$ and $\mathrm{N}-30 \mathrm{~kg} \cdot \mathrm{ha}^{-1}$. During the experiment no pesticides or irrigation were used. The soil type (in terms of granulometry) was sandy loam with a $\mathrm{pH}$ from light acidic to neutral (6.4-6.8).

\subsection{Beetle sampling}

Adult rove beetles were collected using plastic pitfall traps (9 cm diameter) (Lange et al., 2011). Each trap was located in the middle of plots, placed into the ground with the top of the trap at the soil surface. The traps were filled with a 1:1 mixture of water and ethylene glycol. They were emptied weekly from the beginning of the emergence of lupin and spring triticale (the end of Aprilbeginning of May) until the full maturity of lupin (last ten days of July). In total, 13 sampling dates each year were realized, corresponding with the developmental stages of narrow-leafed lupin and spring triticale
(Meier, 2001) (Table 2). Beetles were identified to the species level by a specialist, Andrzej Melke (former worker of Wroclaw University of Environmental and Life Sciences), with the use of different keys (Lohse et al., 1974; Lohse, 1984). If possible, the species were carefully classified to the following feeding groups: zoophagous, saprophagous and parasitoids, on the basis of literature sources (Bohac, 1999; Balog et al., 2008; Belskaya \& Kolesnikova, 2011; Klimaszewski et al., 2013; Yamamoto et al., 2014; Cai et al., 2017). Feeding preferences of species classified as other were not found in the literature. The most abundant species (Amischa analis) was selected for detailed analyses.

\subsection{Statistical analyses}

The data sets of rove beetles were based on the mean values per treatment. The data were normalized with the logarithmic transformation $\log 10$. The total

Table 2. Developmental stages of narrow-leafed lupin and spring triticale (BBCH-scale, Meier [2001]) according to sampling date and year of the study - Stades de développement du lupin à feuille étroite et du triticale de printemps en fonction de la date d'échantillonnage et de l'année d'étude (échelle BBCH, Meier [2001]).

\begin{tabular}{|c|c|c|c|c|c|}
\hline \multirow[t]{2}{*}{ Sampling date } & \multicolumn{3}{|c|}{ Year of study } & \multirow[t]{2}{*}{ Narrow-leafed lupin (BBCH) } & \multirow[t]{2}{*}{ Spring triticale $(\mathrm{BBCH})$} \\
\hline & 2010 & 2011 & 2012 & & \\
\hline 1 & $04 / 27$ & $05 / 08$ & $04 / 30$ & Leaf development (21-23) & Tillering (21-23) \\
\hline 2 & 05/07 & $05 / 04$ & $05 / 15$ & Formation of side shoots (23-26) & Tillering (24-29) \\
\hline 3 & $05 / 13$ & $05 / 12$ & $05 / 22$ & Formation of side shoots (27-29) & Stem elongation (30-35) \\
\hline 4 & $05 / 20$ & $05 / 19$ & $05 / 29$ & Main shoot development (31-39) & Stem elongation (36-40) \\
\hline 5 & $05 / 27$ & $05 / 26$ & $06 / 05$ & Main shoot development (40-45) & Booting (41-45) \\
\hline 6 & $06 / 01$ & $06 / 02$ & $06 / 13$ & Main shoot development (46-52) & Booting (46-49) \\
\hline 7 & $06 / 08$ & $06 / 09$ & $06 / 19$ & Inflorescence emergence (53-57) & Inflorescence emergence (51-59) \\
\hline 8 & $06 / 15$ & $06 / 16$ & $06 / 26$ & Flowering (61-67) & Flowering, anthesis (61-65) \\
\hline 9 & $06 / 23$ & $06 / 22$ & $07 / 04$ & End of flowering (68-69) & Flowering, anthesis (66-69) \\
\hline 10 & $07 / 01$ & $06 / 30$ & $07 / 11$ & Development of the fruit (71-79) & Development of the fruit (71-73) \\
\hline 11 & $07 / 14$ & $07 / 07$ & $07 / 18$ & Ripening (81-83) & Development of the fruit (74-75) \\
\hline 12 & $07 / 21$ & $07 / 15$ & $07 / 24$ & Ripening (84-86) & Development of the fruit (76-77) \\
\hline 13 & $07 / 28$ & $07 / 21$ & $07 / 30$ & Ripening (87-89) & Development of the fruit (76-77) \\
\hline
\end{tabular}


abundance, mean number of species, Margalef's index, and the abundance of specific taxa were analyzed using repeated measures analysis with mixed model (proc mixed function) in SAS University Edition version 9.04 from 2017. The dependent variables were treatment (in 4 variants) and date (in 13 variants). The interaction treatment $x$ date was also analyzed. The random effect was plot and year was the repeated effect (type=arh[1]) (Littell et al., 2006). In the analysis of each year separately, date was used as repeated effect. The heterogeneous first-order autoregressive structure was used for the covariance structure of errors. The appropriate covariance structure was selected by the data characteristic and by comparing the Akaike Information Criterion (AIC) values for various potential covariance structures (Keselman et al., 1998). In order to reveal significant differences between treatments, Tukey's HSD test was performed. In the results, only species, which differed significantly between treatments, were presented. Margalef's diversity index was calculated in a spreadsheet: $\mathrm{D}=(S-1) / \ln N$, where $S$ is the number of species, and $N$ is the total number of individuals in the sample.

The rove beetle community, depending on the experimental treatment, date and year (as environmental variables) and plot (as covariable), was presented on the CCA biplot. The analysis was made in Canoco 4.5 (Ter Braak \& Smilauer, 2002). Samples were permuted within blocks (999 permutations, Monte Carlo test) and the significance in the first and all canonical axes was performed.

\section{RESULTS}

In 2010 , the number of rove beetles was significantly higher in narrow-leafed lupin and spring triticale grown in the pure stands (T1 and T3) in comparison to its mixtures (T4 and T6) (Table 3). In 2011, rove beetle abundance was significantly higher in lupin (T1) and its mixture of $27 \%$ (T3) in comparison to $14 \%$ of lupin seeds (T4) and triticale as pure stand (T6). In 2012, beetles were significantly more numerous in the lupin monoculture (T1) in comparison to all other treatments, and at the same time more rove beetles were found in the spring triticale monocrop (T6) in comparison to T3. Considering the mean number of species, in 2010 it was significantly higher in lupin and triticale sown in the pure stand in comparison to its mixtures. In 2011 and 2012, significantly more staphylinid species were found in lupin grown as pure stand in comparison to all other treatments. Margalef's index, which indicates the species richness, was significantly higher in the lupin pure stand in comparison to both mixtures of plants (in 2010 and 2012), and additionally to spring triticale sown as a monocrop (in 2011).

In the three years of the study the treatment was the mean factor, which influenced the beetle community (Table 4). Significant effects were found in the case of Staphylinidae $(p<0.0019)$, the species Amischa analis $(p=0.05)$, and one trophic group of zoophagous ( $p=$ 0.011 ). All of the analyzed groups, except parasitoids, were significantly influenced by the date. The relation treatment*date significantly affected only the parasitic group $(p=0.01)$.

Staphylinidae as a community were significantly more abundant in the lupin and triticale monocrops in comparison to their mixtures $(p<0.0019)$ (Figure 1a). The abundance of rove beetles differed on particular dates (Figure 1b). In narrow-leafed lupin as a pure stand, a relatively higher number of beetles was observed between the $5^{\text {th }}$ and $10^{\text {th }}$ dates. In spring triticale, the peak of abundance was observed on the $10^{\text {th }}$ date (development of fruit in spring triticale, after the flowering stage in lupin). In both plant mixtures, the abundance of rove beetles was relatively lower on all dates in comparison to plants grown in pure stands. Considering Amischa analis (Figure 2a), this species was significantly more abundant in the lupin as a pure stand in comparison to all treatments. At the same time,

Table 3. Individual number, species number and Margalef's index of rove beetle communities among years of the study - Nombre d'individus, nombre d'espèces et indice de Margalef des communautés de staphylins selon les années de l'étude.

\begin{tabular}{|c|c|c|c|c|c|c|c|c|c|}
\hline \multirow[t]{2}{*}{ Treatment } & \multicolumn{3}{|c|}{ Individual number } & \multicolumn{3}{|c|}{ Mean species number/total species number } & \multicolumn{3}{|c|}{ Margalef's index } \\
\hline & 2010 & 2011 & 2012 & 2010 & 2011 & 2012 & 2010 & 2011 & 2012 \\
\hline 1 & $165^{\mathrm{a}}$ & $218^{\mathrm{a}}$ & $143^{\mathrm{a}}$ & $1.98 \mathrm{a} / 47$ & $2.39^{\mathrm{a}} / 41$ & $2.08 \mathrm{a} / 34$ & $0.82^{\mathrm{a}}$ & $0.96^{\mathrm{a}}$ & $0.97^{\mathrm{a}}$ \\
\hline 3 & $101^{\mathrm{b}}$ & $154^{\mathrm{a}}$ & $75^{\text {bd }}$ & $1.19^{\mathrm{b}} / 31$ & $1.62^{\mathrm{b}} / 29$ & $1.31^{\mathrm{b}} / 26$ & $0.50^{\mathrm{b}}$ & $0.67^{\mathrm{b}}$ & $0.53^{b}$ \\
\hline 4 & $117^{\mathrm{a}}$ & $129^{\mathrm{b}}$ & $105^{\mathrm{b}}$ & $1.25^{\mathrm{b}} / 34$ & $1.66^{\mathrm{b}} / 36$ & $1.52^{\mathrm{b}} / 31$ & $0.51^{\mathrm{b}}$ & $0.68^{\mathrm{b}}$ & $0.68^{b}$ \\
\hline 6 & $144^{\mathrm{a}}$ & $131^{\mathrm{b}}$ & $132^{\mathrm{bc}}$ & $1.83 \mathrm{a} / 46$ & $1.72^{\mathrm{b}} 39$ & $1.64^{\mathrm{b}} / 26$ & 0.73 & $0.60^{\mathrm{b}}$ & $0.71^{b}$ \\
\hline
\end{tabular}

Treatment - traitement: see table 1 - voir tableau $\mathbf{1}$; the same lowercase letters in a column indicate no significant difference (repeated measures analysis with mixed model, $p \leq 0.05$ ) - les mêmes lettres minuscules dans une colonne indiquent qu'il n'y a pas de différence significative (analyse de mesures répétées avec un modèle mixte, $\mathrm{p} \leq 0,05$ ). 
Table 4. Results of repeated measures analysis with mixed model used to test the effect of treatment, date and treatment*date interaction on rove beetle abundance, selected species and ecological groups - Résultats de l'analyse de mesures répétées avec un modèle mixte utilisé pour tester l'effet du traitement, l'effet de la date et l'interaction traitement*date sur l'abondance des staphylins, les espèces sélectionnées et les groupes écologiques.

\begin{tabular}{|c|c|c|c|c|c|c|c|c|c|}
\hline \multirow[t]{2}{*}{ Group } & \multicolumn{3}{|c|}{ Treatment } & \multicolumn{3}{|c|}{ Date } & \multicolumn{3}{|c|}{ Treatment*date } \\
\hline & $\overline{\mathrm{dF}}$ & $\mathbf{F}$ & $p$ & $\overline{\mathrm{dF}}$ & $\mathbf{F}$ & $p$ & $\mathrm{dF}$ & $\mathbf{F}$ & $p$ \\
\hline Staphylinidae & 3 & 5.04 & $<0.0019$ & 12 & 4.46 & $<0.0001$ & 36 & 0.61 & 0.97 \\
\hline Amischa analis & 3 & 2.56 & 0.05 & 12 & 2.32 & 0.007 & 36 & 1.20 & 0.20 \\
\hline Zoophages & 3 & 3.77 & 0.011 & 12 & 3.49 & $<0.0001$ & 36 & 0.53 & 0.99 \\
\hline Parasitoids & 3 & 0.76 & 0.51 & 12 & 1.66 & 0.071 & 36 & 1.64 & 0.01 \\
\hline Saprophages & 3 & 2.12 & 0.097 & 12 & 2.35 & 0.006 & 36 & 0.84 & 0.73 \\
\hline
\end{tabular}

$\mathrm{dF}$ : degrees of freedom - degrés de liberté; F: value from Fisher's test - valeur du test de Fisher; $p$ : propability value — valeur de probabilité.

a

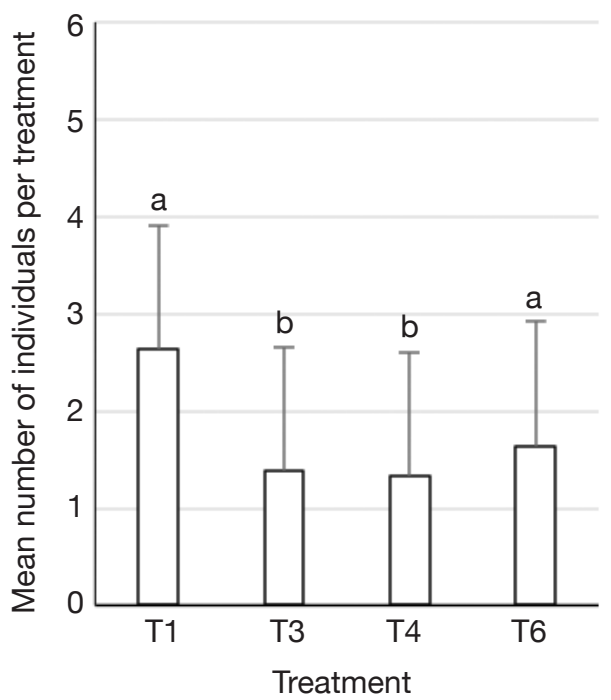

b

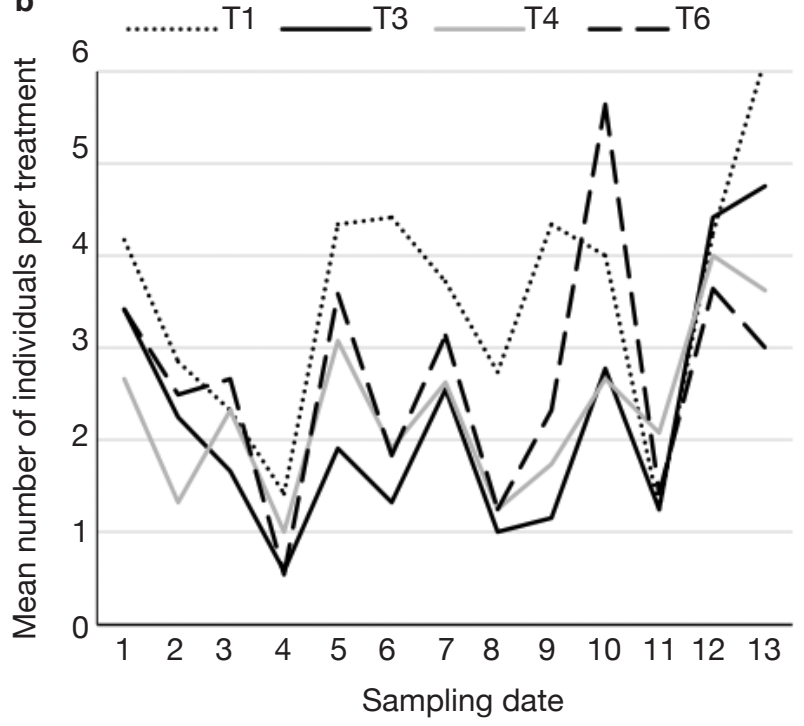

Figure 1. Total mean number of rove beetles per treatment (see table 1) for the 3-year study (a) and the mean numbers of rove beetles on each sampling date (see table 2) (b) - Nombre moyen total de staphylins par traitement (voir tableau 1) pour les trois années d'études (a) et abondance moyenne des communautés de staphylins à chaque date d'échantillonnage (voir tableau 2) (b).

Different lower case letters indicate significant differences between treatments (repeated measures analysis with mixed model, $p \leq 0.05)$ - les différentes lettres minuscules sur le graphique indiquent des différences significatives entre les traitements (p $\leq 0,05)$.

significantly more beetles were found in both mixtures of plants in comparison to spring triticale. In narrowleafed lupin the peaks of abundance of this species were observed in the $1^{\text {st }}$ (leaf development) and in $4-5^{\text {th }}$ (stem elongation stage) dates (Figure 2b).In spring triticale, the highest numbers of $A$. analis were observed in $1^{\text {st }}$ (tillering stage) and $7-8^{\text {th }}$ (flowering stage) dates. The peak of abundance in the mixture of $27 \%$ of lupin seeds was between peaks observed for plants grown in the pure stand, followed by the peak of the mixture of $14 \%$ of lupin seeds.
The dominant trophic groups in all treatments were zoophagous, then parasitoids, and the least, saprophagous (Figure 3a). Only zoophagous abundance differed between treatments $(p=0.011)$ (Table 1). This group was significantly more numerous in lupin and spring triticale monocrops in comparison to its mixtures. However, in the case of parasitoids no significant difference was found, with relatively more individuals that occurred in lupin in comparison to other treatments. Considering the interaction treatment*date, some significant effects were found 
a

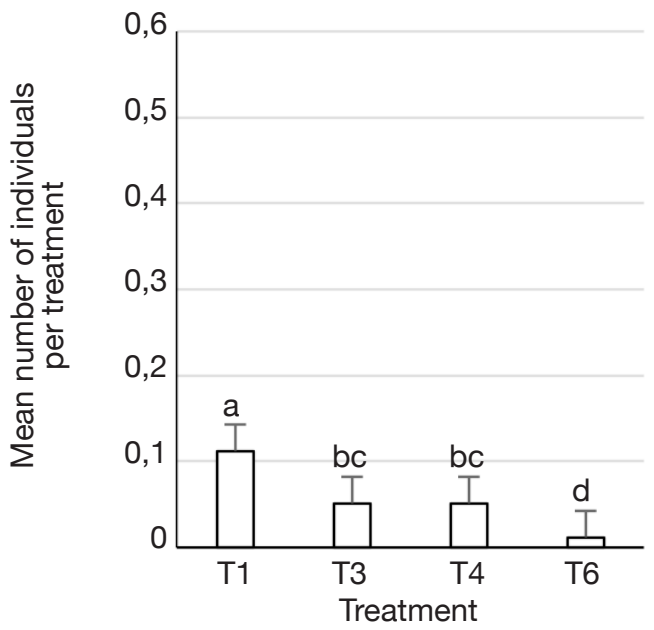

b

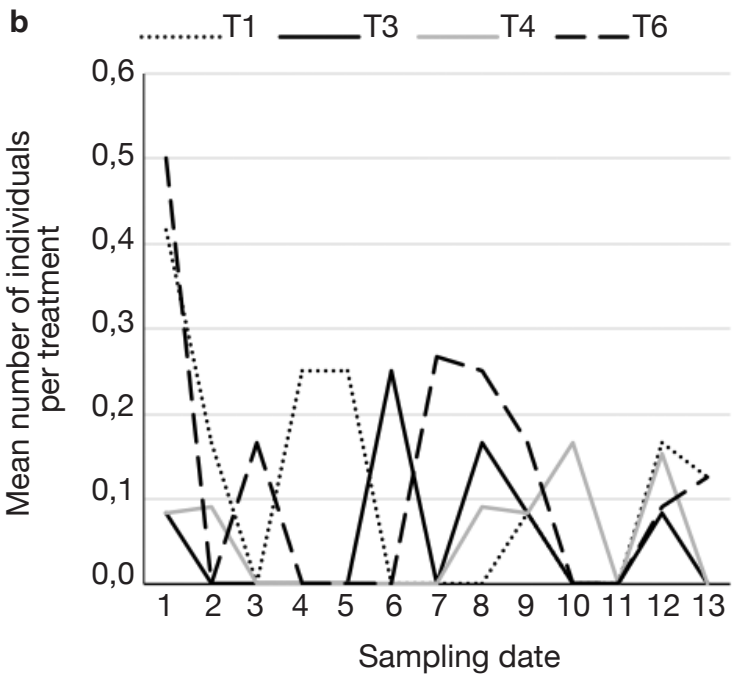

Figure 2. Mean abundance of Amischa analis for the 3-year study (a) and its mean number on each sampling date (see table 2) (b) - Nombre moyen total de l'espèce Amischa analis par traitement pour les trois années d'études (a) et son abondance moyenne à chaque date d'échantillonnage (voir tableau 2) (b).

Different lower case letters indicate significant differences between treatments (repeated measures analysis with mixed model, $p \leq 0.05)$ - les différentes lettres minuscules sur le graphique indiquent des différences significatives selon les traitements (analyse de mesures répétées avec un modèle mixte, $\mathrm{p} \leq 0,05)$.
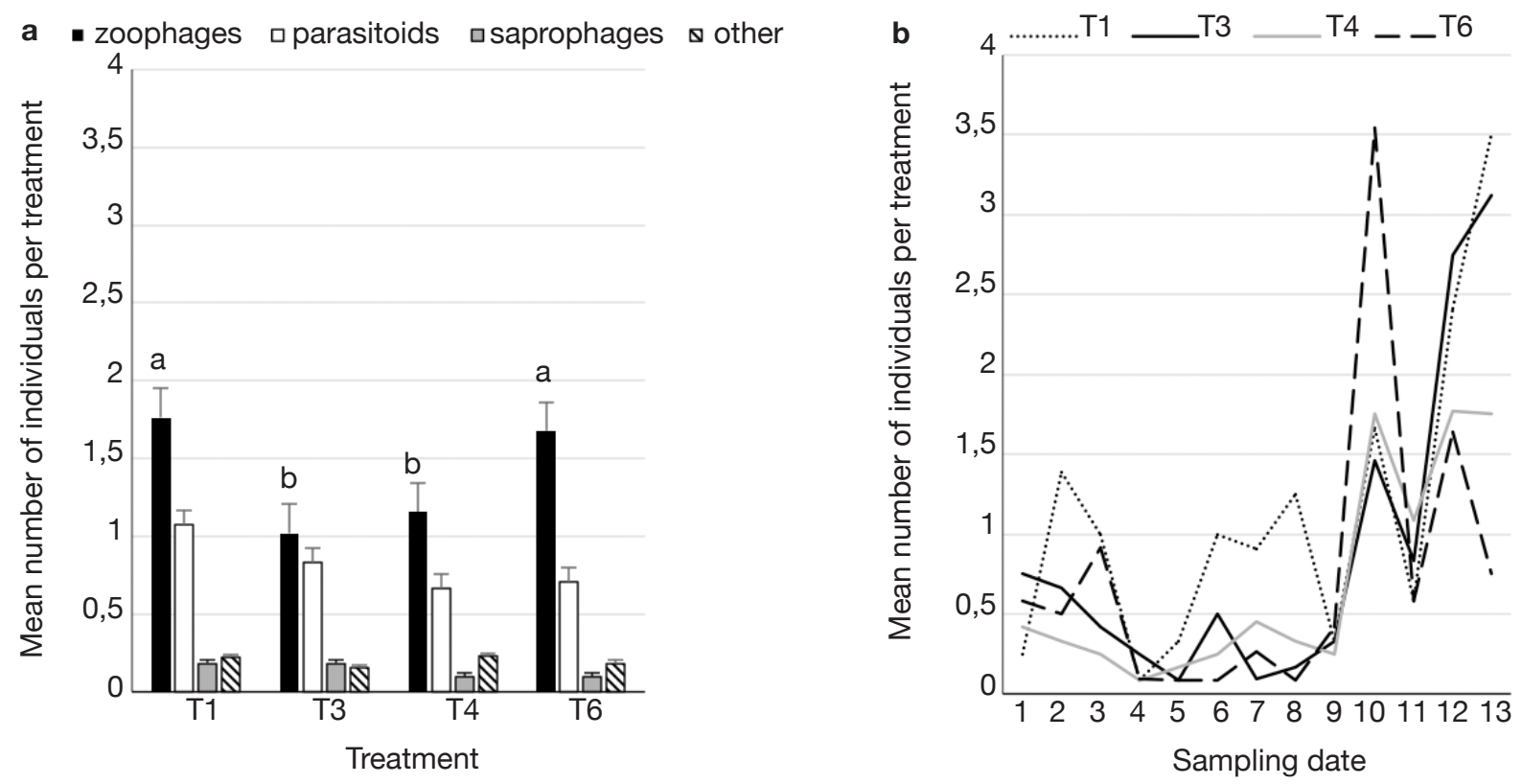

Figure 3. Mean abundance of zoophagous, parasitoids, saprophagous and other Staphylinidae per treatment (see table 1) (a) and mean abundance of parasitoids on each sampling date (see table 2) (b) - Abondance moyenne de Staphylinidae zoophages, parasitoüdes, saprophages et autres par traitement (voir tableau 1) (a) et abondance moyenne des parasitö̈des à chaque date d'échantillonnage (voir tableau 2) (b).

Different lower case letters indicate significant differences between treatments (repeated measures analysis with mixed model, $p \leq 0.05)$ - les différentes lettres minuscules sur le graphique indiquent des différences significatives selon les traitements (analyse de mesures répétées avec un modèle mixte, $\mathrm{p} \leq 0,05$ ). 
$(p=0.01)$ (Figure 3b, table 1). On almost all dates significantly more rove beetles in the abundance of all analyzed groups occurred in lupin as the pure stand in comparison to other treatments. On the $10^{\text {th }}$ date (development of fruit of cereal) significantly more beetles were found in spring triticale. Considering the effect of plant mixtures, only on the last two dates were significantly more beetles found in the mixture, with $27 \%$ of lupin seeds in comparison to lupin as the pure stand and the second mixture of plants.

During the 3-year study, a total of 100 rove beetle species were sampled. Species were plotted relatively evenly along the first and second CCA axes (Figure 4). The first canonical axis explained $37.8 \%$ of variance $(p=$ $0.002)$, and the second canical axis $18.6 \%$ of variance $(p=0.002)$. The analyzed factors were: experimental treatment, year of the study, and date of sampling. It was found that the saprophagous species, e.g. Anotylus insecatus and Omalium validum, occurred on the right side of the diagram, while parasitic species (Aleochara genus) occurred on the left side. This was presumably related to the year of the study. The group of species occurring on the upper left side of the diagram was related to the sampling date. The effect of plots was relatively weak, considering the short vectors. The vectors of lupin (T1) and spring tricitale (T6) were in opposition to the vectors of plant mixtures $(\mathrm{T} 3, \mathrm{~T} 4)$.

\section{DISCUSSION}

During the three years of the study over 1,600 adult rove beetles were collected and 100 species were identified. Such great abundance and diversity has enabled us to conduct a complex analysis of the response of Staphylinidae to plant diversity in field conditions. In a study conducted by Russell (1989), it was concluded that enemies (such as predatory and parasitic beetles) generally occur more frequently or are more effective in polycultures than in monocultures. Booij et al. (1997) found significantly higher predator activity and density in the intercropping of cabbage with clover. However, there are some doubts as to whether natural enemies inhabit polycultures for a longer time or only visit them accidentally. Regarding this problem, Russel (1989) argued that populations of generalized predators and parasitoids are more stable in polycultures because of the wide variety of herbivores, which are available at different times. In contrast to the assumptions and results of other experiments (Russel, 1989; Booij et al., 1997), the abundance and diversity of rove beetle decreased in the more diverse habitat (the mixtures of plants) in comparison to narrow-leafed lupin. This effect was also observed in the case of spring triticale, but only in selected years and groups. The high beetle abundance and diversity in lupin can be explained by the development of a relatively large canopy (e.g. in comparison to triticale) during the vegetation season (Duthion et al., 1994). Crops that develop a larger canopy create a better microclimate in the field for epigeic and soil-dwelling arthropods (Gailis \& Turka, 2013). The other reason might be lupin flowers, which attract the adults of parasitic rove beetles from Aleochara spp. (Wang et al., 2017). Similar results were found by Hurej \& Twardowski (2006) regarding ground beetle abundance in yellow-lupin intercropped with spring triticale. The authors found significantly more predatory ground beetles in the lupin monoculture and in the intercrop with the highest proportion of lupin. The question is why these insects also occurred in high numbers and diversity in triticale. In the other experiments (Hurej et al., 2013; Hurej et al., 2014) carried out in the same intercropping design, a relatively lower abundance of pests, like aphids, weevils and thrips was observed in intercropped treatments in comparison to plants grown in a pure stand. Herbivores, in contrast to predators, have a generally negative response to plant diversity. In more detail, the response might be negative for specialists and not significant for generalists (Dassou \& Tixier, 2016). Perhaps the greater rove beetle abundance in lupin or triticale might be the effect of better food supply, which mostly constitutes different pests. However, it is known that intercropping may increase the diversity of herbivores (Siemann et al., 1998), and generalist predators like rove beetles will only benefit from it. Another hypothesis is the influence of the interspecific competition between rove beetle species, which causes their lower abundance in intercropping. This was observed in some rove beetle genera, like Gyrophaena, or Aleochara (Betz et al., 2018). Another possible explanation for the relatively high abundance of rove beetles in spring triticale might be the effect of the accidental migration of these organisms on the field.

It was also assumed that there would be a different response of particular trophic groups to intercropping, and especially that zoophagous groups would react positively to higher plant diversity in plant mixtures. This was only in part true. In our study zoophagous species were more abundant in lupin and spring triticale monocrops, while parasitic staphylinid numbers increased with the higher number of the yellow lupin seeds in the field (not significant). Clough et al. (2007) found some differences in the response of rove beetle trophic groups to organic or conventional farming. Detritivorous and fungivorous groups were found more frequently in organic farming, which was directly related to their food supply. Unexpected zoophagous activity-density was significantly greater in a conventional field (Clough et al., 2007). In the present study zoophagous species reached greater 


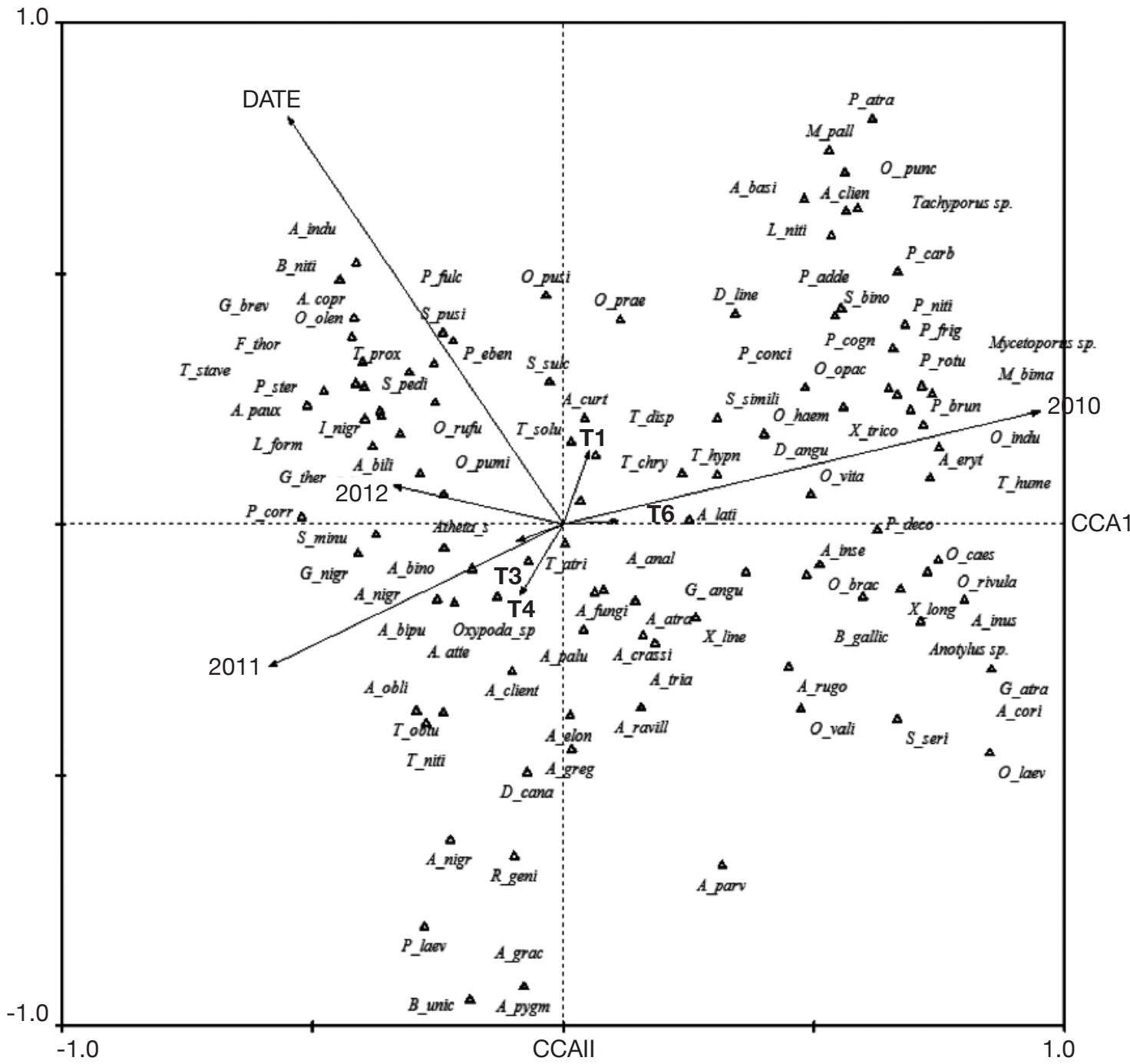

Figure 4. CCA biplot of Staphylinidae communities depending on treatment and date - Biplot CCA des communautés de Staphylinidae en fonction du traitement et de la date.

A_anal: Amischa analis; A_atra: Atheta atramentaria; A_atte: Acrotona atterima; A_basi: Atheta basicornis; A_bili: Aleochara bilineata; A_bino: Aleochara binotata; A_bipu: Aleochara bipustulata; At_cli: Atheta clientula; A_clie: Acrotona clientula; A_copr: Aleochara coprochara spp.; A_cori: Atheta coriaria; A_cras: Atheta crassicornis; A_curt: Aleochara curtula; A_elon: Atheta elongatula; A_euryt: Aleochara erythroptera; A_fung: Atheta fungi; A_grac: Alevonota gracilenta; A_greg: Aloconota gregaria; A_indu: Atheta induta; A_inse: Anotylus insecatus; A_inus: Anotylus inustus; A_lati: Atheta laticollis; A_nigr: Amischa nigrofusca; A_obli: Atheta oblita; A_palu: Atheta palustris; A_parv: Acrotona parvula; A_paux: Aleochara pauxila; A_pygm: Acrotona pygmaea; A_ravi: Atheta ravilla; A_rugo: Anotylus rugosus; A_tria: Atheta triangulum; B_gall: Bledius gallicus; B_niti: Bisnius nitidulus; B_unic: Bledius unicornis; D_angu: Dinaraea angustula; D_cana: Drusilla canaliculata; D_line: Dinaraea linearis; F_thor: Falagria thoracica; G_angu: Gyrohypnus angustatus; G_atra: Gyrohypnus atratus; G_brev: Gabrius breviventer; G_nigr: Gabrius nigritulus; G_ther: Gabronthus thermarum; I_nigr: Ilyobates nigricollis; L_form: Leptacinus formicetorum; L_niti: Liogluta nitidula; O_brac: Oxypoda brachyptera; O_caes: Omalium caesum; O_haem: Oxypoda haemorrhoa; O_indu: Oxypoda induta; O_laev: Othius laeviusculus; O_olen: Ocypus olens; O_opac: Oxypoda opaca; O_prae: Oxypoda praecox; O_pumi: Oligota pumilio; O_punc: Othius punctulatus; O_pusi: Oligota pusilima; O_rivu: Omalium rivulare; O_rufu: Oxyporus rufus; O_vali: Omalium validum; O_vita: Oxypoda vitata; M_bima: Mycetoporus bimaculatus; $\mathbf{M} \_$pall: Meotica pallens; $\mathbf{P} \_$adde: Philonthus addendus; $\mathbf{P} \_$atra: Philonthus atratus; $\mathbf{P} \_b r u n:$ Plataraea brunnea; P_carb: Philonthus carbonarius; $\mathbf{P} \_c o g n:$ Philonthus cognatus; $\mathbf{P} \_c o n c:$ Philonthus concinnus; $\mathbf{P} \_c o r r:$ Philonthus corruscus; $\mathbf{P} \_$deco: Philonthus decorus; $\mathbf{P}$ _eben: Philonthus ebenius; $\mathbf{P} \_$frig: Philonthus frigidus; $\mathbf{P} \_$fulv: Platydracus fulvipes; $\mathbf{P} \_l a e v:$

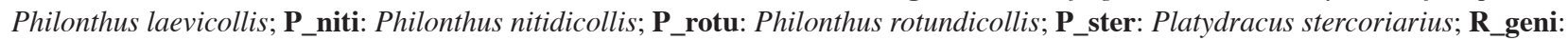
Rugilus geniculatus; S_bino: Sepedophilus binotatus; S_mitu: Scopaeus minutus; S_pedi: Sepedophilus pedicularius; S_pusi: Scopeus

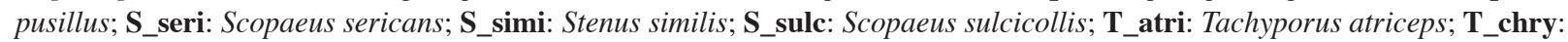
Tachyporus chrysomelinus; T_disp: Tachyporus dispar; T_hume: Tachinus humeralis; T_hypn: Tachyporus hypnorum; T_niti: Tachyporus nitidulus; T_obtu: Tachyporus obtusus; T_prox: Tachinus proximus; T_solu: Tachyporus solutus; T_tras: Tachyporus trasversalis; $\mathbf{X} \_l i n e:$ Xantholinus linearis; $\mathbf{X} \_l o n g:$ Xantholinus longiventris; $\mathbf{X} \_$tric: Xantholinus tricolor. 
numbers in crops sown in the pure stand in comparison to plant mixtures. Bryan \& Wratten (1984) found that higher staphylinid abundance might be expected in fields with higher aphid densities. The reason is that those predatory staphylinids have been shown to aggregate in areas of high prey density. Indeed, in other experiments in the same experimental design high numbers of aphids were found in lupin (Hurej et al., 2013; Hurej et al., 2014). Also, the CCA biplot showed some slight differences in the response of rove beetles to intercropping (especially in the case of saprophagous species and parasitoids). In the case of zoophagous species this effect was not observed.

\section{CONCLUSIONS}

Intercropping is described as a practice that increases the abundance of beneficial insects and decreases the number of pests. The effect of intercropping was studied on the whole staphylinid community, trophic groups and selected species. Contrary to what was hypothesized, rove beetle abundance and diversity decreased in the mixtures of plants in comparison to narrow-leafed lupin and spring triticale monocrops in our research. This was also shown for the zoophagous group. Other trophic groups were not affected by intercropping. Generally, the higher rove beetle abundance in lupin and spring triticale sown in pure stands might be the result of better food supply in monocultures during the whole vegetation season. Additionally, narrow-leafed lupin creates a better habitat for beetles, taking into account relative canopy development and flowers that attract beneficial organisms.

\section{Acknowledgements}

This research was carried out with the financial support of Polish Ministry of Science and Higher Education, under grant NN 310441538. We would like to thank Mr Andrzej Melke for his support in rove beetle species identification.

\section{Bibliography}

Altieri M.A., 1991. Traditional farming in Latin America. Ecologist, 21, 93-96.

Altieri M.A. \& Letourneau D.K., 1982. Vegetation management and biological control in agroecosystems. Crop Prot., 1, 405-430.

Andow D.A., 1999. Vegetational diversity and arthropod population response. Annu. Rev. Entomol., 36, 561-586.

Balog A., Markó V. \& Szarvas P., 2008. Dominance, activity density and prey preferences of rove beetles (Coleoptera: Staphylinidae) in conventionally treated Hungarian agro-ecosystems. Bull.Entomol. Res., 9, 343-353.
Belskaya E.A. \& Kolesnikova A.A., 2011. Species composition and ecological characteristics of rove beetles (Coleoptera, Staphylinidae) in the Southern Taiga of the Middle Urals. Entomol. Rev., 91, 123137.

Betz O., Irmler U. \& Klimaszewski J., 2018. Biology of rove beetles (Staphylinidae). Life history, evolution, ecology, and distribution. Cham, Switzerland: Springer.

Birken E.M. \& Cloyd R.A., 2007. Food preference of the rove beetle Atheta coriaria Kraatz (Coleoptera: Staphylinidae) under laboratory conditions. Insect Sci., 14, 53-56.

Birkhofer K., Wolters V. \& Diekötter T., 2014. Grassy margins along organically managed cereal fields foster trait diversity and taxonomic distinctness of arthropod communities. Insect Conserv. Diversity, 7, 274-287.

Bohac J., 1999. Staphylinid beetles as bioindicators. Agric. Ecosyst. Environ., 74, 357-372.

Booij C.J.H., Noorlander J. \& Theunissen J., 1997. Intercropping cabbage with clover: effects on ground beetles. Biol. Agric. Hortic., 15, 261-268.

Bryan K.M. \& Wratten S.D., 1984. The responses of polyphagous predators to prey spatial heterogeneity: aggregation by carabid and staphylinid beetles to their cereal aphid prey. Ecol. Entomol., 9, 251-259.

Cai Ch. et al., 2017. Mycophagous rove beetles highlight diverse mushrooms in the Cretaceous. Nat. Commun., 8 , DOI: $10.1038 /$ ncomms 14894

Clough Y., Kruess A. \& Tschrantke T., 2007. Organic versus conventional arable farming systems: functional grouping helps understand staphylinid response. Agric. Ecosyst. Environ., 118, 285-290.

Dassou A.G. \& Tixier P., 2016. Response of pest control by generalist predators to local-scale plant diversity: a meta-analysis. Ecol. Evol., 6, 1143-1153.

Duthion C., Ney B.\& Munier-Jolain N., 1994. Development and growth of white lupin: implications for crop management. Agron. J., 86, 1039-1045.

Gailis J. \& Turka I., 2013. Discussion on ground beetles and rove beetles as indicators of sustainable agriculture in Latvia: review. In: Treija S. \& Skujeniece S., eds. Proceedings of annual $19^{\text {th }}$ international scientific conference "Research for rural developmen", 1517 May 2013, University of Agriculture, Jelgava, Latvia, $56-62$.

Good J. \& Giller P.S., 1991. The diet of predatory Staphylinid beetles - a review of records. Entomol. Mon. Mag., 127, 77-89.

Hurej M. \& Twardowski J.P., 2006. The influence of yellow lupin intercropped with spring triticale on predatory carabid beetles (Coleoptera: Carabidae). Eur. J. Entomol., 103, 259-261.

Hurej M., Twardowski J. \& Kozak M., 2013. Weevil (Coleoptera: Curculionidae) assemblages in the fields of narrow-leafed lupin sown as pure stand and intercropped with spring triticale. Zemdirbyste, 100, 393-400. 
Hurej M., Kucharczyk H., Twardowski P.J. \& Kozak M., 2014. Thrips (Thysanoptera) associated with narrow-leafed lupin (Lupinus angustifolius L., 1753) intercropped with spring triticale (x Triticosecale Wittm. Ex.A. Camus, 1927). Rom. Agric. Res., 31, 337-345.

Keselman H.J., James A., Kowalchuk R.K. \& Wolfinger R.D., 1998. A comparison of two approaches for selecting covariance structures in the analysis of repeated measurements. Commun. Stat. Simul. Comput., 27, 591-604.

Klimaszewski J. et al., 2013. Molecular and microscopic analysis of the gut contents of abundant rove beetle species (Coleoptera, Staphylinidae) in the boreal balsam fir forest of Quebec, Canada. Zookeys, 20, 1-24.

Kosewska A., Nietupski M., Nijak K. \& Skalski T., 2016. Effect of plant protection on assemblages of ground beetles (Coleoptera, Carabidae) in pea (Pisum L.) and lupine (Lupinus L.) crops. Period. Biol., 118, 213-222.

Krooss S. \& Schaefer M., 1998. The effect of different farming systems on epigeic arthropods: a five-year study on the rove beetle fauna (Coleoptera: Staphylinidae) of winter wheat. Agric. Ecosyst. Environ., 69, 121-133.

Lange M., Gossner M.M. \& Weisser W.W., 2011. Effect of pitfall trap type and diameter on vertebrate by-catches and ground beetle (Coleoptera: Carabidae) and spider (Araneae) sampling. Methods Ecol. Evol., 2, 185-190.

Lithourgidis A.S., Dordas C.A., Damalas C.A. \& Vlachostgergios D.N., 2011. Annual intercrops: an alternative pathway for sustainable agriculture. Aust. J. Crop Sci., 5, 396-410.

Littell R.C. et al., 2006. SAS for mixed models. $2^{\text {nd }}$ ed. Cary, NC, USA: SAS Institute Inc.

Lohse G., 1984. Nachtrag zum Verzeichnis der Mitteleuropeischen Kaefer. Entomol. Blätter, 80, $143-$ 152.

Lohse G., Benick G. \& Likowski Z., 1974. Staphylinidae II (Hypocyphtinae and Aleocharinea). Pselaphinae. In: Freude H., Harde K.W. \& Lohse G.A. Die Käfer Mitteleuropas - Systematik. Germany: Springer Spektrum.

Meier U., 2001. Growth stages of mono-and dicotyledonous plants. Berlin, Germany: Federal Biological Research Centre for Agriculture and Forestry.

Obrtel R., 1971. Soil surface coleoptera in a lowland forest. Acta Sci. Nat. Acad. Sci. Bohemoslov., 7, 1-47.

Petremand G., Fleury D., Castella E. \& Delabays N., 2016. Ground cover influence on Carabidae (Coleoptera) populations and potential interest for bio-control of some vineyards pests. Biotechnol. Agron. Soc. Environ., 20, 375-385.
Purtauf T., Dauber J. \& Wolters V., 2002. The response of carabids to landscape simplification differs between trophic groups. Oecologia, 142, 458-464.

Root R.B., 1973. Organization of plant-arthropod association in simple and diverse habitats: the fauna of collards (Brassica olearacea). Ecol. Monogr., 43, 95-124.

Russel E.P., 1989. Enemies hypothesis: a review of the effect of vegetational diversity on predatory insects and parasitoids. Environ. Entomol., 18, 590-599.

Siemann E., Tilman D., Haarstad J. \& Ritchie M., 1998. Experimental tests of the dependence of arthropod diversity on plant diversity. Am. Nat., 152, 738-750.

Smith J., Potts S.G., Woodcock B.A. \& Eggleton P., 2008. Can arable field margins be managed to enhance their biodiversity, conservation and functional value for soil macrofauna? J. Appl. Ecol., 45, 269-278.

Ter Braak C.J.F. \& Smilauer P., 2002. CANOCO reference manual and CanoDraw for Windows user's guide: software for canonical community ordination (version 4.5). Ithaca, NY, USA: Microcomputer power.

Theunissen J., 1994. Intercropping in field vegetable crops: pest management by agrosystem diversification-an overview. Pest Manage. Sci., 42, 65-68.

Tooker J.F. \& Frank S.D., 2012. Genotypically diverse cultivar mixtures for insect pest management and increased crop yields. J. Appl. Ecol., 49, 974-985.

Vandermeer J.H., 1989. The ecology of intercropping. Cambridge, UK: Cambridge University Press.

Vásquez-Vélez L., Bermúdez C., Chacón P. \& LozanoZambrano F., 2010. Analysis of the richness of Staphylinidae (Coleoptera) on different scales of a sub-Andean rural landscape in Colombia. Biodivers. Conserv., 19, 1917-1931.

Wang W., Chen G., Li C. \& Sun W., 2017. Floral characteristics and pollination ecology of Manglietia ventii (Magnoliaceae), a plant species with extremely small populations (PSESP) endemic to South Yunnan of China. Plant Divers., 39, 52-59.

Yamamoto S., Ikeda K. \& Kamitani S., 2014. Species diversity and community structure of rove beetles (Coleoptera: Staphylinidae) attracted to dung of sika deer in coniferous forests of southwest Japan. Entomol. Sci., 17, 52-58.

Zerche L., 1994. Die Revision der Oxypoda-Typen aus der Sammlung Claudius Rey im Musée Guimet d'Histoire naturelle de Lyon und einiger anderer Typen der Gattung sowie die Beschreibung von vier neuen Oxypoda-Arten (Coleoptera, Staphylinidae, Aleocharinae). Coleoptera, 6, 1-36.

(45 ref.) 